\title{
Impact of bedside open lung biopsies on the management of mechanically ventilated immunocompromised patients with acute respiratory distress syndrome of unknown etiology
}

\author{
Emmanuel Charbonney $M D^{a, *}$, John Robert MD $^{b}$, Jean-Claude Pache $M D^{c}$, \\ Jean-Claude Chevrolet $M D^{a}$, Philippe Eggimann $M D^{d}$
}

\author{
antensive Care, Geneva University Hospital, 1211 Geneva, Switzerland \\ ${ }^{\mathrm{b}}$ Thoracic Surgery, Geneva University Hospital, 1211 Geneva, Switzerland \\ ${ }^{c}$ Clinical Pathology, Geneva University Hospital, 1211 Geneva, Switzerland \\ ${ }^{\mathrm{d}}$ Department of Intensive Care Medicine and Burn Center, CHUV, 1011 Lausanne, Switzerland
}

\section{Keywords: \\ Acute respiratory distress syndrome; \\ Surgical biopsy; Immunocompromised; \\ Bedside}

\begin{abstract}
Background: Open lung biopsy (OLB) is helpful in the management of patients with acute respiratory distress syndrome (ARDS) of unknown etiology. We determine the impact of surgical lung biopsies performed at the bedside on the management of patients with ARDS.

Methods: We reviewed all consecutive cases of patients with ARDS who underwent a surgical OLB at the bedside in a medical intensive care unit between 1993 and 2005.

Results: Biopsies were performed in 19 patients mechanically ventilated for ARDS of unknown etiology despite extensive diagnostic process and empirical therapeutic trials. Among them, 17 (89\%) were immunocompromised and 10 patients experienced hematological malignancies. Surgical biopsies were obtained after a median (25\%-75\%) mechanical ventilation of 5 (2-11) days; mean $( \pm \mathrm{SD}) \mathrm{PaO}_{2} /$ $\mathrm{FiO}_{2}$ ratio was $119.3( \pm 34.2) \mathrm{mm} \mathrm{Hg}$. Histologic diagnoses were obtained in all cases and were specific in 13 patients (68\%), including $9(47 \%)$ not previously suspected. Immediate complications (26\%) were local (pneumothorax, minimal bleeding) without general or respiratory consequences. The biopsy resulted in major changes in management in 17 patients $(89 \%)$. It contributed to a decision to limit care in 12 of 17 patients who died.

Conclusion: Our data confirm that surgical OLB may have an important impact on the management of patients with ARDS of unknown etiology after extensive diagnostic process. The procedure can be performed at the bedside, is safe, and has a high diagnostic yield leading to major changes in management, including withdrawal of vital support, in the majority of patients.
\end{abstract}

(C) 2009 Elsevier Inc. All rights reserved.

Abbreviations: ARDS, acute respiratory distress syndrome; BAL, bronchoalveolar lavage; OLB, open lung biopsy.

* Corresponding author. Critical Care Department, St Michael's Hospital, Toronto, Ontario, Canada M5B 1W8.

E-mail addresses: charbonneye@smh.toronto.on.ca (E. Charbonney), john.robert@hcuge.ch (J. Robert), jean-claude.pache@hcuge.ch (J.-C. Pache), jean-claude.chevrolet@hcuge.ch (J.-C. Chevrolet), philippe.eggimann@chuv.ch (P. Eggimann). 


\section{Introduction}

Acute respiratory distress syndrome (ARDS) is a frequent cause of long duration of mechanical ventilation in critically ill patients [1]. Guidelines for the management of this syndrome include the identification of all possible causes susceptible to benefit from a specific treatment [2,3]. Nevertheless, despite an extensive diagnostic process, including sophisticated imaging techniques (high-resolution computed tomodensitometry, nuclear magnetic resonance, positron emission tomography) and microbiology (cultures, serology-based and polymerase chain reaction-based detection of microorganisms in the blood or in specimens obtained through bronchoalveolar lavage [BAL]), the etiology of ARDS remains unknown in $5 \%$ to $10 \%$ of patients $[4,5]$.

In worsening ARDS of unidentified cause, many clinicians empirically combine broad spectrum antimicrobial agents with immunosuppressive therapy as steroids, and the impact of such potentially contradictory strategies may itself contribute to worsen the prognosis [6,7]. In this situation, lung tissue histologic examination may be useful, particularly in immunocompromised patients as suggested from older series $[8,9]$. Hence, surgical biopsy is a recognized accurate diagnostic method for diffuse lung disease in immunocompetent patients [10]. In patients with respiratory distress, many authors suggest that surgical open lung biopsies (OLBs) can be performed safely with a high diagnosis yield $[11,12]$, even if the they have hematologic diseases [13]. Papazian et al [14] reported in 1998 a very low rate of complications and suggested that such procedure may be performed at the bedside.

We reviewed specifically our local surgical OLBs performed at the bedside of patients with ARDS of unknown etiology after extensive diagnostic process and requiring mechanical ventilation for persistent respiratory failure despite aggressive empirical treatments. The scope was to evaluate whether that procedure had brought an impact on the management or treatment decision in these patients.

\section{Patients and methods}

We identified retrospectively all patients hospitalized in the medical intensive care unit (ICU) of our institution with ARDS who underwent a bedside surgical OLB between 1993 and 2005. This unit is a tertiary and teaching hospital with 1500 beds, with an average of 1500 admissions every year for a median length of stay of 3 days. The ethical committee of the institution approved the extraction of data from the medical charts. Potential cases were identified through a review of the operative protocols of the thoracic surgery and completed by an electronic search in the database of the Department of Clinical Pathology. Patients with documented ARDS were then included. Acute respiratory distress syndrome was defined as brutal onset event, severe hypoxemia $\left(\mathrm{Po}_{2} / \mathrm{FiO}_{2}\right.$ ratio, $\left.<200 \mathrm{~mm} \mathrm{Hg}\right)$, with bilateral infiltrates on chest $\mathrm{x}$-ray, and a pulmonary capillary wedge pressure of less than $18 \mathrm{~mm} \mathrm{Hg}$, or no evidence of heart failure on echocardiography [15].

\subsection{Extraction of the data}

Data extracted from the medical records and files were demographic characteristics, reason for admission, underlying diseases, operation report, and histology from lung biopsies. We also extracted characteristics of eventual organ failures, parameters of mechanical ventilation, oxygenation parameters, and catecholamine requirements on the day of surgery for lung biopsy. All diagnostic procedures performed before the biopsy were recorded (cellular characteristics of BAL; imaging documents; complete available microbiological information, including serology). We then look at potential local complications related to surgery (air leak, pneumothorax, and bleeding) and at the impact on the management of the patients after biopsy.

\subsection{Surgical procedure and histology analysis}

The surgical lung biopsy was carried out at the patient's bedside in the intensive care unit by 2 surgeons. Anesthesia was provided by midazolam or propofol, combined with sulfentanyl, completed by nondepolarizing neuromuscular blocking agents. All patients were mechanically ventilated for their respiratory failure, through an orotracheal low-cuff pressure single-lumen tube. The orotracheal tube used in every patient was not changed, that is, for a selective bronchial intubation device. When pulmonary infiltrates were bilateral and homogeneous, preference was given to a left-sided approach for a resection of the tip of the lingula as described by Miller et al [16].

The axillary-anterior incision, approximately $5 \mathrm{~cm}$ long, was carried out under the breast, to gain access to the upper edge of the sixth rib. When present, pleural fluid was collected for bacteriologic and/or cytologic purposes. The 2 adjacent ribs were kept apart with a retractor. The tip of the lingula was then exteriorized and resected with a mechanical GIA-type stapler, the ventilator being disconnected during the stapling. The piece of lung retrieved was sent for extensive microbiological and pathologic examinations, the latter like a frozen section. A single chest tube was introduced into the pleural cavity through the incision itself, and the incision was closed in 3 layers with resorbable material (including the skin). The whole procedure took 30 to 45 minutes, and the chest tube was removed a couple of days later, after having checked for the absence of any air leak and/or excessive fluid output $(>150 \mathrm{~mL} / \mathrm{d})$. Biopsies were analyzed within 24 to 48 hours from a pathologist with expertise in lung diseases. All cases were discussed in a multidisciplinary meeting that included intensivists, pathologists, surgeons, pneumologists, and infectiologists or onco-hematologists, and additional tests were performed when appropriate. 


\section{Results}

Of 54 patients who underwent a surgical lung biopsy in the institution, 19 open biopsies were performed in the medical ICU at the bedside for ARDS between 1993 and 2005. The 19 patients represented around $8 \%$ to $10 \%$ of all ARDS and their characteristics at the time of biopsy are summarized in Table 1. As described in Table 2, a majority (89\%) of the patients were immunocompromised and many received long-term corticosteroids. Two patients were not immunosuppressed and developed an ARDS after cardiac and plastic surgery, respectively. All patients received broad spectrum antimicrobials for suspected infection.

The diagnostic workup performed before selection for a bedside surgical OLB is listed in Table 3. All but one patient had a bronchoscopic BAL 2 to 5 days before the biopsy, with systematic analysis of cellular content and extensive microbiological workup. Cellular content was nonspecific and microbiological results were negative in all cases. Two polymerase chain reaction procedures performed on material obtained from BAL gave false-positive results (Pneumocystis jiroveci, herpes simplex virus), not confirmed by culture and/ or the biopsies. All patients had a high-resolution computed tomography of the lung, which revealed nonspecific diffuse interstitial involvement with various degrees of alveolar involvement in all cases.

The biopsy was performed at the lingula in 12 patients $(63 \%)$, at the right lower lobe in $4(21 \%)$, and in 3 others at the left lower lobe, the right middle lobe, and the right upper lobe, respectively. Other locations than lingula were chosen, either for technical reasons or because of more dense opacity. Histology obtained from biopsies are summarized in Table 4. Biopsies resulted in a histologic diagnosis in all patients. A

Table 1 Characteristics of the patients at time of the surgical OLB

\begin{tabular}{|c|c|}
\hline \multicolumn{2}{|l|}{ Characteristics } \\
\hline Age $(y)$, mean \pm SD & $50 \pm 15$ \\
\hline Male sex, n (\%) & $11(57.9)$ \\
\hline $\begin{array}{l}\text { Patients under immunosuppressive } \\
\text { treatment before the biopsy, } \mathrm{n}(\%)\end{array}$ & $17(89.5)$ \\
\hline Neutropenic patients, $\mathrm{n}(\%)$ & $7(36.8)$ \\
\hline Empirical broad spectrum antibiotic, n (\%) & $19(100)$ \\
\hline Antifungal therapy, n (\%) & $8(42.1)$ \\
\hline Antiviral therapy, n (\%) & $4(21.1)$ \\
\hline Organ system failure, median $(25 \%-75 \%)$ & $2(2-3)$ \\
\hline $\mathrm{PaO}_{2} / \mathrm{Fio}_{2}$ ratio $(\mathrm{mm} \mathrm{Hg})$, mean $\pm \mathrm{SD}$ & $119.3 \pm 34.2$ \\
\hline PEEP the day of biopsy $\left(\mathrm{cm} \mathrm{H}_{2} \mathrm{O}\right)$, mean \pm SD & $6 \pm 3$ \\
\hline $\begin{array}{l}\text { Duration of mechanical ventilation before } \\
\text { the biopsy (d), median }(25 \%-75 \%)\end{array}$ & $5(2-11)$ \\
\hline $\begin{array}{l}\text { Total duration of mechanical ventilation }(\mathrm{d}) \text {, } \\
\text { median }(25 \%-75 \%)\end{array}$ & $11(5-31)$ \\
\hline Vasopressor requirement before the biopsy, n (\%) & $14(73.7)$ \\
\hline Surgical open biopsy of the lingula, $\mathrm{n}(\%)$ & $13(68.4)$ \\
\hline
\end{tabular}

specific diagnosis was reached in 13 patients (68\%), which was not previously suspected in 9 patients $(47 \%)$. Nine patients had a diagnosis of diffuse alveolar damage, with evidence of a fibroproliferative stage in 4 of them. An unspecific diagnostic procedure was made in 6 patients $(32 \%)$. The lingula gave a similar yield of specific diagnosis compared to other sites ( $66 \%$ vs $57 \%$ ).

An infection was documented in 7 cases: cytomegalovirus in 4 , hematogenously spread disseminated Candida albicans, and $P$ jiroveci pneumonia which was negative on BAL performed 2 days before surgery in each, respectively. A respiratory syncytial virus grew from culture of the biopsy in an additional case initially scored as nonspecific pneumonia compatible with a viral infection. No bacteria grew from culture of the tissue except a small amount of coagulase-negative Staphylococcus in 1 case which was interpreted as a contaminant.

\subsection{Impact of the biopsies on the treatment of the patients}

The impact of the biopsies on the treatment of each patient is listed in Table 4. Biopsies resulted in changes (simple or multiple) in the treatment in 17 patients $(89 \%)$, as summarized in Table 5. The treatment was not changed in only 2 patients. One patient with histology of diffuse alveolar damage, corresponding to the exsudative phase of a secondary ARDS. The other patient died before the identification of an unexpected $P$ jiroveci pneumonia for which a specific treatment could not be given.

\subsection{Outcome}

Only 2 patients (11\%) could be weaned from mechanical ventilation and were discharged alive from the ICU (Table 4). The median of total duration of mechanical ventilation was 11 (5-31) days. Fourteen of the 17 patients who died developed persistent multiple organ failure or unresponsive hypoxemia. The median time (range) between lung biopsies and death was 10 (3-27) days.

However, only 5 died from organ failure that did not respond to maximal treatment. The biopsy resulted in a direct withdrawal of vital support in 3 patients owing to the reported diagnosis (severe lung fibrosis in 2 and carcinomatous lymphangitis in 1) among the context of worsening critical state of the patient. It resulted in a main contribution to the decision to limit the extent of the care in 9 additional patients, and all ultimately died from further withdrawal of vital support.

\subsection{Adverse effects of surgery}

Local complications developed after surgery in 5 patients (26\%). A pneumothorax requiring the insertion of an additional chest tube developed in 2 patients, and surgery 
Table 2 Immunosuppression description ${ }^{\mathrm{a}}$

\begin{tabular}{|c|c|c|}
\hline $\begin{array}{l}\text { Patient } \\
\text { (sex [F/M]; age }[\mathrm{y}])\end{array}$ & $\begin{array}{l}\text { Main underlying diseases } \\
\text { at ICU admission }\end{array}$ & $\begin{array}{l}\text { Immunosuppressive therapy before } \\
\text { development of the ARDS }\end{array}$ \\
\hline 1. $(\mathrm{F} ; 41)$ & Acute myeloid leukemia, M5 type & $\begin{array}{l}\text { Bone marrow transplantation, } \\
\text { cyclosporine, neutropenia }\end{array}$ \\
\hline 2. $(\mathrm{M} ; 54)$ & Acute myeloid leukemia, M6 type & Bone marrow transplantation, neutropenia \\
\hline 3. $(\mathrm{M} ; 17)$ & Acute biphenotypic leukemia & Bone marrow transplantation, neutropenia \\
\hline 4. $(\mathrm{M} ; 46)$ & Clinical suspicion of idiopathic lung fibrosis & High-dose corticosteroids, chronic alcoholism \\
\hline 5. $(\mathrm{F} ; 66)$ & Goodpasture syndrome & High-dose corticosteroids, cyclophosphamid \\
\hline 6. $(\mathrm{M} ; 58)$ & Lung transplantation 22 months ago & Tacrolimus, mycophenolate, and corticosteroids \\
\hline 7. (M; 47) & Epidermoid carcinoma of the esophagus & $\begin{array}{l}\text { Corticosteroids for late phase of a } \\
\text { postoperative ARDS }\end{array}$ \\
\hline 8. $(\mathrm{F} ; 63)$ & Liver cirrhosis (hepatitis C) and sarcoidosis & Long-term corticosteroids \\
\hline 9. $(\mathrm{M} ; 22)$ & Acute myeloid leukemia, M4 type & Bone marrow transplantation, corticosteroids \\
\hline 10. $(\mathrm{M} ; 49)$ & Hodgkin disease, stage IIA & Induction chemotherapy, neutropenia \\
\hline 11. (M; 52) & Aplastic anemia & $\begin{array}{l}\text { Autologous stem cell } \\
\text { transplantation, cyclosporine, neutropenia }\end{array}$ \\
\hline 12. $(\mathrm{M} ; 45)$ & Clinical suspicion of idiopathic lung fibrosis & High-dose corticosteroids \\
\hline 13. (F; 41) & Chronic myeloid leukemia, granulomatosis & $\begin{array}{l}\text { Bone marrow transplantation, cyclosporine, } \\
\text { neutropenia }\end{array}$ \\
\hline 14. $(\mathrm{F} ; 67)$ & Plastic surgery (after breast cancer) & None \\
\hline 15. (F; 66) & Hodgkin disease, stage IVB & High-dose corticosteroids \\
\hline 16. (M; 69) & Cardiac surgery (valve replacement & None \\
\hline 17. (F; 73) & Hodgkin disease, stage IVB & Induction chemotherapy, neutropenia, corticosteroids \\
\hline 18. (F; 52) & Paracolic abscess (actinomyces) & Corticosteroids for 2 wks \\
\hline 19. (M; 39) & Acute myeloid leukemia, M2 type & $\begin{array}{l}\text { Bone marrow transplantation, } \\
\text { tacrolimus, mycophenolate }\end{array}$ \\
\hline
\end{tabular}

was necessary for persistent air leak in one of them. A blood loss of more than $200 \mathrm{~mL}$ required transfusion in 2 patients of 4 and $3 \mathrm{U}$ of red cells, respectively. These 2 patients also sustained a thrombopenia before the biopsy, and both required additional hematologic support by transfusion of 2 and $4 \mathrm{U}$ of thrombocytes, respectively. No patient required transfusion of fresh frozen plasma.

\section{Discussion}

Our data confirm that surgical OLB for ARDS of unknown etiology is safe and may provide important information susceptible to induce major changes in the management of these patients. This has already been previously suggested by several series, including in immunocompromised patients in whom empirical treatment of all potential etiologies may be detrimental [11-14,17] and in early-stage ARDS of suspected noninfectious origin [18]. In addition, despite many theoretical advantages and encouraging preliminary reports, transbronchial biopsies may not represent a good alternative to surgical OLB in severely ill ventilated ARDS patients [19-21].

A particular interest of our small retrospective series is that all biopsies have been performed in the ICU at the bedside of mechanically ventilated patients. This allowed us to avoid moving these patients to the operative room, a procedure known to be associated with potential important morbidity in critically ill patients [22].

The biopsy resulted in major change in the management of $17(89 \%)$ of the 19 patients. This finding is consistent with those of previous reports and emphasizes the usefulness of surgical OLBs in worsening ARDS [11,13,14,23,24]. We observed a very high mortality rate $(89 \%)$, due to multiple organ disorders of the patients and the severity of their organic damage. However, and more importantly, the fatal issue resulted from a decision to limit the extent of the care directly related to the result of the biopsy in 12 patients, including a rapid withdrawal in 3 of them. Accordingly, the

Table 3 Diagnostic workup before biopsy

\begin{tabular}{lc}
\hline Type of investigation & No. of patient (\%) \\
\hline Bronchoscopic BAL & $18(94.7)$ \\
Transbronchial biopsy & $1(5.2)$ \\
BAL cell content examination & $18(94.7)$ \\
Lung fluid $^{\text {b }}$ and blood microbiology & $19(100)$ \\
Fungi and parasites search & $19(100)$ \\
PCR $^{\text {a }}$ for respiratory viruses in BAL & $3(15.8)$ \\
Computer tomography & $19(100)$ \\
\hline a Polymerase chain reaction, introduced in 2002. \\
b Bronchoalveolar lavage or tracheal aspiration.
\end{tabular}


Table 4 Histology obtained from surgical OLBs: impact on treatment and final outcome

\begin{tabular}{|c|c|c|c|c|c|}
\hline $\begin{array}{l}\text { Patient } \\
\text { (sex }[\mathrm{F} / \mathrm{M}] \text {; age }[\mathrm{y}])\end{array}$ & $\begin{array}{l}\text { Site of } \\
\text { biopsy }\end{array}$ & $\begin{array}{l}\text { Histologic finding } \\
\text { of the lung biopsy }\end{array}$ & $\begin{array}{l}\text { Complications } \\
\text { of the biopsy }\end{array}$ & $\begin{array}{l}\text { Modifications in treatment } \\
\text { according to the results } \\
\text { of the biopsy }\end{array}$ & $\begin{array}{l}\text { Outcome, } \\
\text { cause of death }\end{array}$ \\
\hline 1. (F; 41) & $\begin{array}{l}\text { Right } \\
\text { upper } \\
\text { lobe }\end{array}$ & $\begin{array}{l}\text { Pneumonia due to } \\
\text { Pneumocistis jiroveci }\end{array}$ & Pneumothorax & No, dead before results & $\begin{array}{l}\text { Death, day } 2 \text { right } \\
\text { heart failure }\end{array}$ \\
\hline 2. $(\mathrm{M} ; 54)$ & $\begin{array}{l}\text { Right } \\
\text { lower } \\
\text { lobe }\end{array}$ & $\begin{array}{l}\text { Diffuse alveolar damage; } \\
\text { cytomegalovirus infection }\end{array}$ & None & $\begin{array}{l}\text { Yes, start of gancyclovir } \\
\text { and broad spectrum } \\
\text { antibiotics stopped }\end{array}$ & $\begin{array}{l}\text { Death, day } 4 \\
\text { CNS hemorrhage }\end{array}$ \\
\hline 3. $(\mathrm{M} ; 17)$ & Lingula & Cytomegalovirus infection & None & $\begin{array}{l}\text { Yes, start of gancyclovir } \\
\text { and broad spectrum } \\
\text { antibiotics stopped }\end{array}$ & $\begin{array}{l}\text { Death, day } 24^{\text {a }} \\
\text { multiple organ failure }\end{array}$ \\
\hline 4. $(\mathrm{M} ; 46)$ & Lingula & $\begin{array}{l}\text { Diffuse carcinomatous } \\
\text { lymphangitis }\end{array}$ & None & Yes, withdrawal of vital support & $\begin{array}{l}\text { Death, day } 2 \\
\text { refractory hypoxemia }\end{array}$ \\
\hline 5. $(\mathrm{F} ; 66)$ & Lingula & Cytomegalovirus infection & Hemorrhage & $\begin{array}{l}\text { Yes, start of gancyclovir and } \\
\text { high-dose corticosteroids stopped }\end{array}$ & $\begin{array}{l}\text { Death, day } 2^{\mathrm{a}} \\
\text { multiple organ failure }\end{array}$ \\
\hline 6. $(\mathrm{M} ; 58)$ & $\begin{array}{l}\text { Right } \\
\text { middle } \\
\text { lobe }\end{array}$ & $\begin{array}{l}\text { Acute rejection grade A3 } \\
\text { (bronchiolitis obliterans) }\end{array}$ & None & $\begin{array}{l}\text { Yes, start of high dose of } \\
\text { corticosteroids } \\
\text { and of cyclosporine }\end{array}$ & $\begin{array}{l}\text { Survival, discharged } \\
\text { on day } 10\end{array}$ \\
\hline 7. $(\mathrm{M} ; 47)$ & Lingula & $\begin{array}{l}\text { Hematogenous abscesses } \\
\text { (Candida albicans) }\end{array}$ & None & $\begin{array}{l}\text { Yes, start of amphotericine B } \\
\text { and corticosteroids stopped }\end{array}$ & $\begin{array}{l}\text { Survival, discharged } \\
\text { on day } 28\end{array}$ \\
\hline 8. (F; 63) & Lingula & $\begin{array}{l}\text { Diffuse alveolar damage in } \\
\text { fibroproliferative phase }\end{array}$ & Hemorrhage & $\begin{array}{l}\text { Yes, increase of corticosteroids } \\
\text { and broad spectrum } \\
\text { antibiotics stopped }\end{array}$ & $\begin{array}{l}\text { Death, day } 10^{a} \\
\text { multiple organ failure }\end{array}$ \\
\hline 9. $(\mathrm{M} ; 22)$ & Lingula & $\begin{array}{l}\text { Histologic damage related } \\
\text { to busulfan toxicity }\end{array}$ & None & $\begin{array}{l}\text { Yes, increase of corticosteroids } \\
\text { and broad spectrum } \\
\text { antibiotics stopped }\end{array}$ & $\begin{array}{l}\text { Death, day } 10^{a} \\
\text { refractory hypoxemia }\end{array}$ \\
\hline 10. (M; 49) & Lingula & $\begin{array}{l}\text { Diffuse alveolar damage; } \\
\text { in exsudative phase }\end{array}$ & None & $\begin{array}{l}\text { Yes, broad spectrum } \\
\text { antibiotics stopped }\end{array}$ & $\begin{array}{l}\text { Death, day } 46^{\mathrm{a}} \\
\text { multiple organ failure }\end{array}$ \\
\hline 11. (M; 52) & $\begin{array}{l}\text { Right } \\
\text { lower } \\
\text { lobe }\end{array}$ & $\begin{array}{l}\text { Diffuse alveolar damage; } \\
\text { in fibroproliferative phase }\end{array}$ & None & $\begin{array}{l}\text { Yes, increase of corticosteroids } \\
\text { and broad spectrum antibiotics } \\
\text { stopped }\end{array}$ & $\begin{array}{l}\text { Death, day } 33^{\text {a }} \\
\text { multiple organ failure }\end{array}$ \\
\hline 12. $(\mathrm{M} ; 45)$ & Lingula & $\begin{array}{l}\text { Diffuse alveolar damage; } \\
\text { in fibroproliferative phase }\end{array}$ & None & $\begin{array}{l}\text { Yes, adaptation of corticosteroids } \\
\text { and broad spectrum antibiotics } \\
\text { stopped }\end{array}$ & $\begin{array}{l}\text { Death, day } 34 \\
\text { refractory hypoxemia }\end{array}$ \\
\hline 13. $(\mathrm{F} ; 41)$ & $\begin{array}{l}\text { Right } \\
\text { lower } \\
\text { lobe }\end{array}$ & $\begin{array}{l}\text { Diffuse alveolar damage; } \\
\text { in exsudative phase; TE }\end{array}$ & None & $\begin{array}{l}\text { Yes, start of defibrotid } \\
\text { (Prociclide, Crinos SpA, } \\
\text { Milan, Italy) }{ }^{\mathrm{b}} \text { and broad } \\
\text { spectrum antibiotics stopped }\end{array}$ & $\begin{array}{l}\text { Death, day } 33 \\
\text { cardiac arrest }\end{array}$ \\
\hline 14. (F; 67) & Lingula & $\begin{array}{l}\text { Histologic pneumonia } \\
\text { with viral inclusions }\end{array}$ & None & Yes start of ribavarin & $\begin{array}{l}\text { Death, day } 33^{\mathrm{a}} \\
\text { refractory hypoxemia }\end{array}$ \\
\hline 15. $(\mathrm{F} ; 66)$ & Lingula & $\begin{array}{l}\text { Lung fibrosis related to } \\
\text { toxicity of bleomycine }\end{array}$ & None & Yes, withdrawal of vital support & $\begin{array}{l}\text { Death, day } 3 \\
\text { refractory hypoxemia }\end{array}$ \\
\hline 16. $(\mathrm{M} ; 69)$ & $\begin{array}{l}\text { Left } \\
\text { lower } \\
\text { lobe }\end{array}$ & $\begin{array}{l}\text { Diffuse alveolar damage; } \\
\text { in exsudative phase }\end{array}$ & None & No & $\begin{array}{l}\text { Death, day } 1 \text { multiple } \\
\text { organ failure }\end{array}$ \\
\hline 17. $(\mathrm{F} ; 73)$ & Lingula & $\begin{array}{l}\text { Lung fibrosis related to } \\
\text { toxicity of bleomycine }\end{array}$ & Pneumothorax & $\begin{array}{l}\text { Yes, adaptation of } \\
\text { corticosteroids and broad } \\
\text { spectrum antibiotics stopped }\end{array}$ & $\begin{array}{l}\text { Death, day } 7^{\text {a }} \\
\text { multiple organ failure }\end{array}$ \\
\hline 18. (F; 52) & $\begin{array}{l}\text { Right } \\
\text { lower } \\
\text { lobe }\end{array}$ & $\begin{array}{l}\text { Diffuse alveolar damage; } \\
\text { cytomegalovirus infection }\end{array}$ & $\begin{array}{l}\text { Surgical air } \\
\text { leakage }\end{array}$ & $\begin{array}{l}\text { Yes, start of gancyclovir and } \\
\text { corticosteroids stopped }\end{array}$ & $\begin{array}{l}\text { Death, day } 36^{\mathrm{a}} \\
\text { refractory hypoxemia }\end{array}$ \\
\hline 19. $(\mathrm{M} ; 39)$ & Lingula & $\begin{array}{l}\text { Diffuse alveolar damage; in } \\
\text { fibroproliferative phase }\end{array}$ & None & Yes, withdrawal of vital support & $\begin{array}{l}\text { Death, day } 8 \\
\text { refractory hypoxemia }\end{array}$ \\
\hline
\end{tabular}


Table 5 Changes in treatment

\begin{tabular}{ll}
\hline Changes & No. of patient (\%) \\
\hline New anti-infectious therapy & $5(26.3)$ \\
New immunosuppressive therapy & $3(15.8)$ \\
Unnecessary antibiotics stopped & $8(42.1)$ \\
Corticosteroids stopped & $3(15.8)$ \\
Change of corticosteroids dosage & $4(21.1)$ \\
Withdrawal of supportive therapy & $3(15.8)$ \\
\hline
\end{tabular}

biopsy allowed to avoid further futile care in 12 (71\%) of 17 patients who ultimately died as a consequence of their ARDS and multiple organ failure.

The 19 patients of the present series were relatively homogenous. All sustained severe forms of ARDS. Extensive diagnostic workup was negative in all of them, and biopsy was only decided after trials of empirical treatments, including broad spectrum antimicrobials and steroids for those suspected to be in the fibroproliferative phase of ARDS [25].

Despite the severity of the ARDS, the procedure was safe. Respiratory failure did not worsen owing to the surgical biopsy. We observed only 5 local complications (26\%), and new surgery for persistent air leakage was required in only 1 patient. These findings are comparable with those of the literature which reported occurrences in $15 \%$ to $25 \%$ of cases $[26,27]$. It is possible that pneumothorax might be avoided by using 2 chest tubes instead of 1 . No patient died as a consequence of surgery, and no change in vasopressor use or immediate oxygenation need was observed. Early death observed in patients 1 and 16 could have been related to the procedure, but no change in intrathoracic pressures or mechanical ventilation was noticed.

Several limitations may limit the extent of the information we can draw from our data. Our small series is not representative of the population sustaining ARDS, but only of a particular subgroup in a majority of immunocompromised patients carefully selected by a multidisciplinary team after negative extended diagnostic assessment and empirical treatments. In contrast to other series [11,14], all our patients were treated with broad spectrum antibiotics at the time of microbiological sampling by BAL, which may have resulted in a lower sensitivity of these examinations. However, none of our patients responded to empirical treatments and, except one hematogenous disseminated candidiasis, the biopsies did show unsuspected infection in 6 patients.

\section{Conclusion}

Surgical OLBs may be safely performed at the bedside of mechanically ventilated patients with ARDS of unknown etiology after extensive diagnostic process and despite empirical therapeutic trials, particularly if they are immunocompromised. The procedure is associated with a high diagnostic yield leading to specific modifications of the management of the patients, including withdrawal and limitation of futile care in a majority of them.

\section{References}

[1] McIntyre RC, Pulido EJ, Bensard DD, et al. Thirty years of clinical trials in acute respiratory distress syndrome. Crit Care Med 2000;28: 3314-31.

[2] Marini JJ, Gattinoni L. Ventilatory management of acute respiratory distress syndrome: a consensus of two. Crit Care Med 2004;32: 250-5.

[3] Dellinger RP, Carlet JM, Masur H, et al. Surviving Sepsis Campaign guidelines for management of severe sepsis and septic shock. Intensive Care Med 2004;30:536-55.

[4] Ware LB, Matthay MA. The acute respiratory distress syndrome. N Engl J Med 2000;342:1334-49.

[5] Marquette $\mathrm{CH}$, Copin MC, Wallet F, et al. Diagnostic tests for pneumonia in ventilated patients: prospective evaluation of diagnostic accuracy using histology as a diagnostic gold standard. Am J Respir Crit Care Med 1995;151:1878-88.

[6] Steinberg KP, Hudson LD, Goodman RB, et al. Efficacy and safety of corticosteroids for persistent acute respiratory distress syndrome. N Engl J Med 2006;354:1671-84.

[7] Adhikari N, Burns KE, Meade MO. Pharmacologic therapies for adults with acute lung injury and acute respiratory distress syndrome. Cochrane Database Syst Rev 2004:CD004477.

[8] Greenman RL, Goodall PT, King D. Lung biopsy in immunocompromised hosts. Am J Med 1975;59:488-96.

[9] McKenna Jr RJ, Mountain CF, McMurtrey MJ. Open lung biopsy in immunocompromised patients. Chest 1984;86:671-4.

[10] Shah SS, Tsang V, Goldstraw P. Open lung biopsy: a safe, reliable and accurate method for diagnosis in diffuse lung disease. Respiration 1992;59:243-6.

[11] Patel SR, Karmpaliotis D, Ayas NT, et al. The role of open-lung biopsy in ARDS. Chest 2004;125:197-202.

[12] Flabouris A, Myburgh J. The utility of open lung biopsy in patients requiring mechanical ventilation. Chest 1999;115:811-7.

[13] Zihlif M, Khanchandani G, Ahmed HP, et al. Surgical lung biopsy in patients with hematological malignancy or hematopoietic stem cell transplantation and unexplained pulmonary infiltrates: improved outcome with specific diagnosis. Am J Hematol 2005; 78:94-9.

[14] Papazian L, Thomas P, Bregeon F, et al. Open-lung biopsy in patients with acute respiratory distress syndrome. Anesthesiology 1998;88: 935-44.

[15] Bernard GR, Artigas A, Brigham KL, et al. The American-European Consensus Conference on ARDS. Definitions, mechanisms, relevant outcomes, and clinical trial coordination. Am J Respir Crit Care Med 1994;149:818-24.

[16] Miller RR, Nelems B, Muller NL, et al. Lingular and right middle lobe biopsy in the assessment of diffuse lung disease. Ann Thorac Surg 1987;44:269-73.

[17] White DA, Wong PW, Downey R. The utility of open lung biopsy in patients with hematologic malignancies. Am J Respir Crit Care Med 2000;161:723-9.

[18] Kao KC, Tsai YH, Wu YK, et al. Open lung biopsy in early-stage acute respiratory distress syndrome. Crit Care 2006;10:R106.

[19] Burt ME, Flye MW, Webber BL, et al. Prospective evaluation of aspiration needle, cutting needle, transbronchial, and open lung biopsy in patients with pulmonary infiltrates. Ann Thorac Surg 1981;32: 146-53.

[20] Rao VK, Ritter J, Kollef MH. Utility of transbronchial biopsy in patients with acute respiratory failure: a postmortem study. Chest 1998;114:549-55. 
[21] Bulpa PA, Dive AM, Mertens L, et al. Combined bronchoalveolar lavage and transbronchial lung biopsy: safety and yield in ventilated patients. Eur Respir J 2003;21:489-94.

[22] Waydhas C. Intrahospital transport of critically ill patients. Crit Care 1999;3:R83-9.

[23] Lachapelle KJ, Morin JE. Benefit of open lung biopsy in patients with respiratory failure. Can J Surg 1995;38:316-21.

[24] Papazian L, Doddoli C, Chetaille B, et al. A contributive result of open-lung biopsy improves survival in acute respiratory distress syndrome patients. Crit Care Med 2007;35:755-62.
[25] Meduri GU, Headley AS, Golden E, et al. Effect of prolonged methylprednisolone therapy in unresolving acute respiratory distress syndrome: a randomized controlled trial. JAMA 1998; 280:159-65.

[26] Hunninghake GW, Zimmerman MB, Schwartz DA, et al. Utility of a lung biopsy for the diagnosis of idiopathic pulmonary fibrosis. Am J Respir Crit Care Med 2001;164:193-6.

[27] Lettieri CJ, Veerappan GR, Helman DL, et al. Outcomes and safety of surgical lung biopsy for interstitial lung disease. Chest 2005;127: 1600-5. 